Illinois State University

ISU ReD: Research and eData

Theses and Dissertations

$10-25-2016$

\title{
Women On The Board Of Directors And Their Impact On The Financial Performance Of A Firm: An Empirical Investigation Of Female Directors In The United States Technology Sector
}

Obinna Mogbogu

Illinois State University, obinna.mogbogu@aun.edu.ng

Follow this and additional works at: https://ir.library.illinoisstate.edu/etd

Part of the Databases and Information Systems Commons

\section{Recommended Citation}

Mogbogu, Obinna, "Women On The Board Of Directors And Their Impact On The Financial Performance Of A Firm: An Empirical Investigation Of Female Directors In The United States Technology Sector" (2016). Theses and Dissertations. 625.

https://ir.library.illinoisstate.edu/etd/625

This Thesis is brought to you for free and open access by ISU ReD: Research and eData. It has been accepted for inclusion in Theses and Dissertations by an authorized administrator of ISU ReD: Research and eData. For more information, please contact ISUReD@ilstu.edu. 
WOMEN ON THE BOARD OF DIRECTORS AND THEIR IMPACT ON THE FINANCIAL

PERFORMANCE OF A FIRM: AN EMPIRICAL INVESTIGATION OF FEMALE

DIRECTORS IN THE UNITED STATES TECHNOLOGY SECTOR

\section{Obinna O. Mogbogu}

\section{Pages}

This study uses a sample of S\&P 500 firms in the United States technology sector to investigate the likely relationship between female directors and financial performance of firms measured by return on average assets and return on average equity as the two accounting based measures of performance. Reasonable theoretical arguments drawn from resource dependency, human capital, agency, and social psychology theory, suggests that the gender diversity of the board of directors may have either a positive, negative, or neutral effect on the financial performance of the firm. Using nonparametric statistics approach, we find a small negative relationship between female directors and financial performance of the firm. Also, we find that the difference in the average measures of financial performance between different levels of female directors on the board is almost identical. The results of our statistical analysis support the theoretical position of a negative relationship between female directors and financial performance of the firm. The policy implications of our study do not support the business case for the inclusion of women on the board of directors in United States technology firms. Our findings in the present study suggest that the appointment of women to the board of directors in firms within the United States technology sector, should be based on criteria other than financial performance. 
KEYWORDS: board composition, board gender diversity, board of directors, corporate governance, female directors, financial performance, gender diversity, technology, united states, women 
WOMEN ON THE BOARD OF DIRECTORS AND THEIR IMPACT ON THE FINANCIAL

PERFORMANCE OF A FIRM: AN EMPIRICAL INVESTIGATION OF FEMALE

DIRECTORS IN THE UNITED STATES TECHNOLOGY SECTOR

OBINNA O. MOGBOGU

A Thesis Submitted in Partial Fulfillment of the Requirements for the Degree of

MASTER OF SCIENCE

School of Information Technology

ILLINOIS STATE UNIVERSITY

2016 
Copyright 2016 Obinna O. Mogbogu 
WOMEN ON THE BOARD OF DIRECTORS AND THEIR IMPACT ON THE FINANCIAL

PERFORMANCE OF A FIRM: AN EMPIRICAL INVESTIGATION OF FEMALE DIRECTORS IN THE UNITED STATES TECHNOLOGY SECTOR

OBINNA O. MOGBOGU

COMMITTEE MEMBERS:

James Wolf, Chair

David Sikolia 


\section{ACKNOWLEDGMENTS}

First, I will like to thank my committee members, Dr. James Wolf and Dr. David Sikolia for guiding me through the successful completion of my master's thesis. I am very blessed to have worked under the supervision of both professors. I shall always speak highly of you both, wherever I go. It has been a pleasure working with you both. I wish you all including your respective family, a happy life.

I will like to thank my advisor, Sarah Jerome, who have been very supportive during the one-year period that I spent working on my thesis. I wish you and your family a wonderful life. I will like to thank Dr. Crowley Paula (Department of Special Education) who also, have been very nice to me as a mother. May the best things of life always continue to find you and your family. I will like thank Dr. Amy Hurd, Dana Davidson, Dr. John Baur, and Sarah Dick for being absolutely nice to me. I wish you all the best in life. I will like to thank Dr. Sarah Walczynski, who not only has been a wonderful professor but also, have been an amazing person. I am glad that I got the chance knowing you before I graduate. Thank you for all the support, as well as, the amazing lectures that you have taught. May all the good things of life come to you and your family. Also to all the professors in the Information Systems department, I wish you all the best in life.

Last, I will like to thank my amazing family, my uncles, Kene and Ajulu, my aunt, Nkem, my dad, my sisters and most importantly my mum who have always supported me in my struggles. Thank you all so much for all the great experiences that we have shared together as a family. My heart goes out to you all. May you all continue to remain blessed, successful, and happy in the years ahead. Shout out to all my friends as well. I wish you all the best in life.

O. O. M. 


\section{CONTENTS}

Page

ACKNOWLEDGMENTS

CONTENTS

TABLES

FIGURES

CHAPTER I: INTRODUCTION 1

CHAPTER II: LITERATURE REVIEW

$\begin{array}{ll}\text { Theoretical Framework } & 4\end{array}$

Resource Dependency Theory 5

$\begin{array}{ll}\text { Human Capital Theory } & 6\end{array}$

$\begin{array}{ll}\text { Agency Theory } & 7\end{array}$

$\begin{array}{ll}\text { Social Theory } & 8\end{array}$

$\begin{array}{ll}\text { Previous Empirical Studies } & 9\end{array}$

Positive Relationship $\quad 9$

Negative Relationship $\quad 11$

$\begin{array}{ll}\text { No Relationship } & 12\end{array}$

$\begin{array}{ll}\text { Null Hypotheses } & 14\end{array}$

$\begin{array}{ll}\text { CHAPTER III: METHOD } & 17\end{array}$

$\begin{array}{ll}\text { Research Design } & 17\end{array}$

$\begin{array}{ll}\text { Sample } & 17\end{array}$

$\begin{array}{ll}\text { Data Gathering Procedure and Variables } & 18\end{array}$ 
$\begin{array}{ll}\text { Statistical Tool and Selected Significance Level } & 21\end{array}$

$\begin{array}{ll}\text { Shapiro Wilks Test Analysis and Results } & 21\end{array}$

Spearman Correlation Analysis and Results 22

$\begin{array}{ll}\text { Kruskal Wallis Rank Sum Test Analysis and Results } & 27\end{array}$

$\begin{array}{ll}\text { CHAPTER V: CONCLUSION } & 34\end{array}$

$\begin{array}{ll}\text { REFERENCES } & 38\end{array}$ 


\section{TABLES}

Table

Page

1. Descriptive Statistics of the Sample Variables

2. Shapiro Normality Test Results

3. Calculated p Values Among Variables

4. Calculated Spearman (rho) Correlation Among Variables

5. First Data Set Showing Average ROAA Between the percentWOBGroup Groups

6. Second Data Set Showing Average ROAE Between the percentWOBGroup Groups

7. Kruskal Wallis Test of First Null Hypothesis Using the First Data Set

8. Kruskal Wallis Test of Second Null Hypothesis Using the Second Data Set 


\section{FIGURES}

Figure

1. Scatterplot diagram showing the monotonic relationship between ROAA and percentWOB variables

2. Scatterplot diagram showing the monotonic relationship between ROAE and percentWOB variables

3. Scatterplot matrix diagram showing the correlation among ROAA, ROAE, and percentWOB variables

4. Average ROAA between two percentWOBGroup groups

5. Average ROAE between two percentWOBGroup groups 


\section{CHAPTER I: INTRODUCTION}

The board of directors acts as an internal governance mechanism via its appointment, supervision and remuneration of senior managers, as well as its framing of corporate strategy (Campbell \& Minguez-Vera, 2008; Minguez-Vera \& Martin, 2011). The board composition in firms is of vital importance within corporate governance, where the aim is to identify structures that align the interests of management and stakeholders (Rose, 2007).

Hillman, Cannella, and Harris (2002) contend that one of the most important trends in the composition of the board over the past two decades has generally been centered on the diversity of the board. There have been several studies on board diversity in the context of a few developed and developing countries, such as in the United States (Carter, Simkins, \& Simpson 2003), Spain (Campbell \& Minguez-Vera, 2008), Norway (Oxelheim \& Randoy, 2003), Turkey

(Ararat, Aksu, \& Tansel, 2010), and Indonesia (Darmadi, 2011). A few number of scholars have also attempted to link the diversity of the board with different aspects within the firm, such as corporate strategic change (Goodstein, Gautam, \& Boeker, 1994), corporate governance (Adams \& Ferreira, 2009), and corporate social performance (Coffey \& Wang, 1998).

In the United States, there has been an ongoing debate regarding the gender diversity of the board in firms. The gender diversity of the board (or board gender diversity) is defined as the number or percentage of women on the board of directors. Many scholars studying the board composition of firms in the United States have attempted to explain the reason behind the underrepresentation of women on the board of directors. In the United States, there are increasing attempts by firms to promote equal opportunity among different groups in the workplace (Ibarra, 1993). The equal employment opportunity commission (EEOC) established in 1965 is used by firms to promote diversity in the United States workforce. Despite many 
attempts by firms in the United States to improve the gender diversity of the board, many evidence suggest that the number of women on the board of directors still remains significantly lower than their male counterparts (Kakabadse, Figueira, Nicolopoulou, Hong Yang, Kakabadse, \& Ozbilgin, 2015).

More recently, the gender diversity of the board has generated debate about the impact of female directors on the performance of the firm. Few scholars have investigated the relationship between female directors and financial performance of the firm. Recent empirical studies have linked the gender diversity of the board with an improved financial performance (Campbell \& Minguez-Vera, 2008; Carter, Simkins, \& Simpson 2003; Erhardt, Werbel, \& Shrader, 2003). However, several other studies have pointed to a negative link between the gender diversity of the board and financial performance of the firm (Adams \& Ferreira, 2009; Minguez-Vera \& Martin, 2011), while several other studies have generally been inconclusive on the link itself ( $\mathrm{N}$. Smith, V. Smith, \& Verner, 2006; Rose, 2007; Farrell \& Hersch, 2005; Shrader, Blackburn, \& Iles, 1997; Carter, D’Souza, Simkins, \& Simpson, 2010).

The key issue is whether the gender diversity of the board will stimulate performance in the firm. In other words, would a more gender diverse board have any impact on the financial performance of the firm? A realistic understanding of the possible relationship between the gender diversity of the board and performance of the firm has several important implications for both public and corporate governance policies in firms. If there is no relationship between the gender diversity of the board and performance of the firm, then the desirability of a gender diverse board becomes a public policy issue. However, if there is a positive relationship between the gender diversity of the board and performance of the firm, then the economic implications of a gender diverse board are important. Furthermore, if the relationship is negative, then the costs 
of inclusion of female directors on the board becomes a factor that is to be considered (Carter, D’souza, Simkins, \& Simpson, 2010).

The present study uses a sample of top technology firms listed in the Standard and Poor's (S\&P) 500 firms for the year 2016. The present study follows a descriptive research approach to investigate the likely relationship between female directors and financial performance of firms in the United States technology sector. Financial performance is measured by return on average assets (ROAA) and return on average equity (ROAE) as the two accounting based measures of firm's performance. The present study is considered to be significant, since it offers the possibility to improve our understanding of the existing business cases for the inclusion of women on the board of directors, particularly in technology firms situated in the United States. Thus, the present study deviates from other research studying diversity at the individual, group or board level alone by investigating the relationship between female directors and financial performance of firms in the context of the United States technology sector.

The remainder of the paper is organized as follows: chapter two reviews the related literature and formulate the hypotheses for the present study. In chapter three, we present the research design. In chapter four, we present the result of the statistical analysis that was conducted in the present study. We conclude the present study with a discussion of the research findings in chapter five. 


\section{CHAPTER II: LITERATURE REVIEW}

\section{Theoretical Framework}

The board of directors provides four important functions to the firm, this include (1) monitoring and controlling managers, (2) providing information and counsel to managers, (3) monitoring compliance with applicable laws and regulations, and (4) linking the corporation to the external environment (Carter, D’Souza, Simkins, \& Simpson, 2010). A number of existing theories have addressed these functions in one way or another. It is argued that the execution of

these functions by the board, is largely dependent on the composition of the board itself. A wellorganized board comprising of the right composition of board members is generally believed to be capable of increasing the firm's performance, by being able to execute all four of the functions mentioned above. This idea offers the possibility that board composition, in regards to the gender diversity of the board, is perhaps, likely related to the performance of the firm.

There are a few number of theories from various fields, which have tried to examine the nature of the relationship between board diversity and financial performance of the firm. However, there is no single theory that is known to have directly predicted the nature of the relationship itself. In this section, we adopt an interdisciplinary approach and draw from four important theories taken from organization theory, economics, and social psychology to provide the theoretical basis for the hypotheses tested. The four theories discussed in this section provide some of the known business cases of a gender diverse board of directors in firms. The four theories we will be reviewing in this section are resource dependency, human capital, agency, and social psychological theory. 


\section{Resource Dependency Theory}

One of several propositions to dominate the business case of a gender diverse board of directors is, the notion that female directors provide a unique set of valuable information to both the board and managers, which helps improve the decision making approach that is undertaken by the board and ultimately, increase the financial performance of the firm (Fama \& Jensen, 1983; Adams \& Ferreira, 2007). A related, but more extensive proposition for the business case of a gender diverse board of directors follows from the resource dependency theory, which posits that a diverse board will bring diverse perspectives and several nontraditional approaches to problem solving. The resource dependency theory provides the basis for some of the most convincing theoretical arguments for the business case of a diverse board of directors.

Pfeffer and Salancik (2003) suggested that the board of directors could serve as a linkage between a corporation and other external organizations to address environmental dependencies. They also suggested the following four benefits for the external linkage that is created by the board of directors: (1) directors deliver valuable resources, such as information and expertise to managers, (2) directors facilitate an open channel of communication with constituents of importance to the firm, (3) directors obtain commitments of support from other important organizations or groups in the external environment, and (4) directors create and supply legitimacy for the firm in the external environment.

The resource dependency theory also posits that a diverse board of directors will be capable of providing unique and valuable information to the entire members of the board, as well as, to the firm's top managers, which could improve the decision making process in the firm and ultimately impact the firm's overall performance. The resource dependency theory also suggests that the difference in the diversity of the board of directors, will make it possible for firms to 
have more access to the labor and product market, as well as, an improved accessibility to a larger and diverse talent pool of human capital resource, which can facilitate the provision and appointment of more female employees into leadership positions in the firm. Furthermore, the resource dependency theory suggest a more diverse board of directors will send a positive signal to the firm's shareholders, its customer base, and the government as well, in order to publicly indicate that the firm values and understands the importance of having a generally diverse workforce composition (Booth \& Deli, 1999; Agrawal \& Knoeber, 2001).

\section{Human Capital Theory}

Terjesen, Sealy, and Singh (2009) used the work of (Becker, 1964) to define the human capital theory as, the individual's value to the organization, in regards to, their wealth of education, work experience, and level of skillsets, which are available and beneficial to the firm The human capital theory predicts that the diversity of the board of directors will have an impact on the firm's performance, as a result of the unique human capital attributes that becomes available from simply having a diverse board of directors. However, the human capital theory warns that the effect of a diverse board of directors on the firm's financial performance could be positive or negative, since it largely depends on the situation, as well as, the approach that a firm has decided to use, in order to derive value from the human capital that is available to them.

This is in accordance with the contingency theory in the sense that the value of the available human capital in one firm at some point in time, may not always remain the same at other given times or situations (Fiedler \& Chemers, 1967; Lawrence \& Lorsch, 1967). In other words, the value of having a woman on the board of directors as a result of her unique set of human capital attributes, may not always result in a positive or negative impact on the firm's 
financial performance; given how the firm uses the available human capital it has on its board of directors to achieve its targeted financial performance.

\section{Agency Theory}

One of the primary functions of the board of directors is the monitoring and controlling of managers in the firm, which is a fundamental concept from the agency theory itself (Jensen \& Meckling, 1976). The role of the board of directors in an agency framework is to resolve agency problems that may exist between managers and shareholders, by compensating the shareholders or replacing the managers that do not create value to the shareholders of the firm (Fama \& Jensen, 1983). One business case for diversity is that the diversity of the board of directors increases the board's independence. This implies that members of a very diverse board of directors are more likely to ask questions and approach problems differently when dealing with managers than a traditionally or less diverse board of directors will. Therefore, making a more diverse board of directors a better monitor of managers than one that is not (Carter, Simkins, \& Simpson, 2003).

From the agency theory, one can assume that there is value in having more women serve on the board of directors, since their presence on the board of directors will make the board more independent and effective at supervising the managers in the firm. However, the agency theory warns that a firm may not achieve any value from simply having women serve on its board of directors. This is likely the case when the women on the board of directors are marginalized from partaking in many of the board of directors' crucial activities that could directly have an impact on the performance of the firm. As more women become increasingly marginalized on the board of directors, the chances are that a firm will lose many of the potential benefits that are assumed to be available in a gender diverse board of directors, such as the board of directors' ability to 
effectively supervise the managers of the firm (Ibarra, 1993). It is important to note that the agency theory does not provide a clear prediction of the link between the diversity of the board of directors and the performance of the firm. However, the agency theory does not dismiss the possibility that the diversity of the board of directors, could be beneficial in some ways to the firm.

\section{Social Theory}

The presence of women on the board of directors is often viewed favorably by corporate stakeholders. However, Westphal and Milton (2000) used the social psychology theory to argue that the presence of women on the board of directors could lower social cohesion between groups, thus creating a social barrier among the members of the board, which could make it more difficult for the number of female directors who are on the board, to have any positive value to both the board's performance and overall firm's performance as well.

The social psychology theory predicts that the individuals who have a majority status on the board (e.g., male directors in most cases), will have the potential to exert an unequal amount of influence in the board's decision making processes than the individuals who have a minority status on the same board (e.g., female directors in this case). Despite the argument by Westphal et al. (2000), which warns of a likely negative effect of board gender diversity on the firm's performance, the social psychology theory still posits that the gender diversity of the board of directors will not impact the board of directors' ability to execute its functions and more so, will not have any influence on the performance of the firm.

Westphal et al. (2000) however suggested that the presence of women on the board of directors may encourage divergent thinking in the decision making process. Consequently, suggesting that a more gender diverse board of directors will produce and enhance creativity, as 
well as, innovation on the board of directors itself. Although, they also suggested that an increased level of diversity on the board of directors could as well, potentially increase conflict among its members. Lau and Murnighan (1998) suggested that the conflict(s) that arises within the board of directors due to its level of diversity, could only make the decision making process suffer by becoming slower and less effective. The social psychology theory uses the contingency theory to suggest that the diversity of the board of directors may lead to either a positive or negative influence on the overall performance of the firm depending on the social dynamic state of the board at different times or situations.

\section{Previous Empirical Studies}

In this section, we review ten past studies in the corporate governance literature that are known to have empirically investigated the relationship between female directors and financial performance of the firm. The results from all ten of these studies have generally been mixed. Some have reported either a positive or negative relationship between female directors and financial performance of the firm, while others have been inconclusive on the subject matter itself. We present all ten empirical studies in the following subsections: (1) positive relationship, (2) negative relationship, and (3) no relationship.

\section{Positive Relationship}

Campbell and Minguez-Vera (2008) adopted a panel data methodology in their study in order to examine the relationship between female directors' participation and firm's value. Tobin's Q was used in their study as the measure of the firm's value. The sample for their panel data analysis in their study consisted of 68 Spanish firms and 408 observations. The data on the board of directors that was used in their study was obtained from the Spanish stock exchange commission (CNMV). Also, they obtained the accounting data for their study from the SABI 
database (Iberian Balance Sheet Analysis System). Campbell et al. (2008) found that the diversity of the board of directors has a positive impact on the firm's value. However, they concluded their study by indicating that the presence of a few number of women on the board of directors alone, was not enough as a factor to have any significant effect on the firm's value. Instead, they suggested that the Spanish firms should focus on balancing the number of women and men on its board of directors, in order to significantly improve the value of the firm.

Using a two-stage least squares regression analysis model, and a sample consisting of 638 Fortune 1000 firms in the year 1997, Carter, Simkins, and Simpson (2003) examined the relationship between the performance of the firm and the gender diversity of the board of directors. The data on the board of directors that was used in their study was obtained from the "Significant Data for Directors 1999: Board Policies and Governance Trends", which was prepared by Directorship. Also, the accounting data for their study was obtained from the COMPUSTAT database. Carter et al. (2003) found a statistically significant positive relationship between the presence of women on the board of directors and the firm's value as measured by Tobin's Q. They concluded their study by suggesting that firms should make more commitments in order to increase the number of women on the board of directors.

Erhardt, Werbel, and Shrader (2003) employed a correlation and regression analysis approach to investigate the relationship between the demographic diversity of the board of directors and the financial performance of the firm. The sample for their study consisted of 112 large firms from across several industries in the United States. The ethnic and gender characteristics of the board of directors were used as the proxy for demographic diversity in their study. They obtained data on the diversity representation in firms from several company reports, which were compiled by Fortune magazine. Financial performance was measured as return on 
assets (ROA) and return on investment (ROI). Also, they used the Compact Disclosure database to obtain data for the 1993 and 1998 financial record of the firms that were examined in their study. Erhardt et al. (2003) found a significant positive relationship between the percentage of females plus ethnic minorities on the board of directors and the financial performance of the firm, measured as ROA and ROI. The result of their analysis remained after controlling for several industries, such as service and production sector. Erhardt et al. (2003) concluded their study by indicating that a firm's image will improve if it considers increasing the diversity of the board of directors. Therefore, they suggested that firms should strongly consider diversifying its board of directors, regardless of whether or not, the diversity of the board of directors impacts the financial performance of the firm; an approach that critics will likely consider as a practice of tokenism, in order to exploit and enhance the firm's public appeal.

\section{Negative Relationship}

Adams and Ferreira (2009) examined the impact of female directors on the financial performance of the firm. The sample for their study consisted of a select number of firms in the Standards and Poor's (S\&P's) 1500 firms from 1996 to 2003. They obtained the data for their study from both the IRRC annual publication and COMPUSTAT ExecuComp database. Adams et al. (2009) found that there is a negative relationship between the percentage of women on the board of directors and the financial performance of the firm, as measure by Tobin's Q. In conclusion, they suggested that firms with an increased gender diverse board of directors, performed worse than firms with a less gender diverse board of directors.

Minguez-Vera and Martin (2011) employed a panel data methodology to investigate the nature of the relationship between female board-membership and financial performance of the firm, as measured by the return on equity (ROE). The data for their study was obtained from the 
SABI database (Iberian Balance Sheet Analysis System) for the period, 1998 to 2003. MinguezVera et al. (2011) found a negative relationship between the presence of women on the board of directors and the financial performance of the firm. The result of their study remained after controlling for a number of named variables, such as level of debt, age of the firm, logarithm of the number of employees, logarithm of total assets, and logarithm of the total number of directors.

\section{No Relationship}

N. Smith, V. Smith, and Verner (2006) used data for the 2,500 largest firms in Denmark during the period 1993 to 2001, to examine the relationship between the diversity of the board of directors and several accounting measures of financial performance. They obtained the data for their study from a private Danish data register called, KOB (Købmandsstandens Oplysningsbureau) and from a second register called, the Statistics Denmark. They found no significant relationship between the gender diversity of the board of directors and a number of several accounting measures of firm's performance. Nevertheless, they concluded their study by suggesting that firms should have a sufficient talent pool of qualified women, who can fill in the top level positions in the firm, such as the board of directors and any of the available executive positons that are opened in the firm.

In another Danish study conducted by Rose (2007), a sample of selected Danish firms were used in a cross-sectional analysis to investigate the relationship between women on the board of directors and the financial performance of the firm, as measured by Tobin's Q. Data on the firms, including their financial information, was obtained from the Copenhagen Stock Exchange during the period 1998 to 2001. Rose (2007) found no significant relationship between 
the number of women on the board of directors and the financial performance of the firm, as measured by Tobin's Q.

Farrell and Hersch (2005) used the Poisson regression method, as well as, an event study to investigate the addition of women on the board of directors in the United States. The Poisson regression method was used to analyze a panel of data from 300 Fortune 1000 firms over a tenyear period from 1990 to 1999. They defined the return on assets (ROA) as the measure of the firm's financial performance. Their study was inconclusive since they were unable to find any relationship between the addition of women to the board of directors and the return on assets. Also, in their study, they found no relationship between the addition of women to the board of directors and the market returns to shareholders.

Shrader, Blackburn, and Iles (1997) used a hierarchical regression method to examine the relationship between the percentage of women on the board of directors and the financial performance of the firm. The financial performance of the firm was measured as the return on sales (ROS), return on assets (ROA), return on investments (ROI), and return on equity (ROE). They obtained the accounting data for their study from the Compact Disclosure database, for a sample of firms in the United States, for years 1992 and 1993. Shrader et al. (1997) found no significant relationship between the percentage of women on the board of directors and the financial performance of the firm. This result remained after controlling for total number of managers, total number of top managers, and total number of board members. They explained the result of their analysis by stating that women had the tendency of being assigned (or marginalized) to assignments, which had less impact on the financial performance of the firm. They also explained that having a few number of women on the board of directors, was simply not enough to yield any significant impact on the financial performance of the firm itself. They 
also questioned the experience of the women who served on the board of directors; thus suggesting that the little experience of women on the board of directors, may explain why the presence of women on the board of directors had no significant impact on the financial performance of the firms that was used in their study.

Carter, D’Souza, Simkins, and Simpson (2010), used a three-stage least squares regression method to analyze a panel data of 641 different firms, which were listed in the Standard and Poor's (S\&P's) 500 index during the period, 1998 to 2002. Data on directors was obtained from the Investor Responsibility Research Center (IRRC) database. Carter et al. (2010) found no significant relationship between any of the gender and performance variables that were used in their study. Also, they did not find any significant relationship between the number of women on the board of directors' committees and Tobin's Q, as well as, return on assets, which were both used as a measure of the firm's financial performance. Using the contingency theory to explain the result of their analysis, they indicated that under some conditions, the effect of board diversity on the financial performance of the firm was varied and thus, understood to be either positive or negative. Therefore, suggesting that the financial value of having women on the board of directors did not always yield the same result under varying situations or time periods. Furthermore, they indicated that the changing results of a positive or negative effect on the financial performance of the firm, may have canceled out over a given period of time; therefore, leaving no measurable result to account for a direct linkage between the diversity of the board of directors and the financial performance of the firm.

\section{Null Hypotheses}

Despite signs of a positive link in both the resource dependency and human capital theory, there still is no definite and direct prediction of a positive relationship between a diverse 
board of directors and the financial performance of the firm. The agency theory offers the possibility that the performance of the firm could be improved by diversifying the members of its board of directors. This way, the board of directors can become a better monitor of management, which can as well, improve the performance of the firm. However, Adams and Ferreira (2009) warned that firms with a diverse board of directors, which offered a more and tougher monitor of management, may not necessarily yield a positive effect on the board of directors' performance, as well as, on the overall performance of the firm. Although the agency theory does suggest a positive link between the diversity of the board of directors and the firm's performance, yet, it still remains unclear what the true nature of the link is.

Two important functions of the board of directors include monitoring and controlling of managers, and strategic decision making to name a few. The social psychological theory posits that a diverse board of directors may not have any influence on the board's decision making ability due to the internal group dynamics that exist in a diverse board of directors. Although it is likely that a diverse board of directors will promote creative and innovative ideas, yet the social psychological theory warns that due to the dynamic nature of a diverse board of directors, conflicts among its members may increase, which could negatively affect the decision making capabilities of the board and consequently impair the overall performance of the firm.

We adopted an interdisciplinary set of theories from the economics and social psychology discipline to understand the business case of board gender diversity in firms. The business case for a gender diverse board have largely been mixed, with signs of a positive, negative and even a no relationship between female directors and firm's performance. In this chapter, we reviewed ten past studies that have empirically investigated the possible relationship between female directors and financial performance of the firm. From this studies, we find that the nature of the 
relationship between female directors and financial performance of the firm have largely been mixed. Using a sample of United States technology firms listed in the S\&P 500 firms for the year 2016 and return on average assets (ROAA) as the measure of firm's financial performance, we thus state the first null hypothesis for the present study as follows:

- $\mathrm{H}_{0}$ : The difference in mean of ROAA between the different percentage levels of women on the board of directors is identical.

- $\mathrm{H}_{1}$ : The difference in mean of ROAA between the different percentage levels of women on the board of directors is not identical.

Likewise, using the return on average equity (ROAE) as the measure of financial performance, we thus state our second null hypothesis for the present study as follows:

- $\mathrm{H}_{0}$ : The difference in mean of ROAE between the different percentage levels of women on the board of directors is identical.

- $\mathrm{H}_{1}$ : The difference in mean of ROAE between the different percentage levels of women on the board of directors is not identical.

The percentage of women on the board of directors is the percentage ratio of women on the board of directors and total board size-comprising of all the members of the board. The two accounting measures of performance used in the present study are ROAA and ROAE. In addition to testing the null hypotheses for the present study, we shall also investigate the degree of relationship (i.e. correlation) that exist between female directors and financial performance of the firm. In the next chapter, we will present our research method and design used in obtaining and analyzing the data included in our sample for the present study. 


\section{CHAPTER III: METHOD \\ Research Design}

The present study follows a descriptive research approach and employs some nonparametric statistics techniques to analyze the data included in the sample. The selected statistics techniques were based on the normal distribution of the data included in the sample. Nonparametric statistics is applied extensively throughout in the present study to analyze and test the two null-hypotheses stated in the previous chapter (see Null Hypotheses).

\section{Sample}

Our sample for the present study consists of 49 publicly traded firms-in the United States technology sector-listed in the S\&P 500 firms for the year 2016. Our choice of sample is based on the following reasons: (1) The S\&P 500 firms includes the top 500 publicly traded firms in the United States; (2) the S\&P 500 firms captures approximately 80 percent coverage of available market capitalization in the United States; (3) the S\&P 500 firms is largely regarded by many investors as a good representation of the United States stock market and economy.

The technology firms included in our sample are all listed in the S\&P 500 firms and are assumed to be among the top 500 firms in the United States. All of the 49 firms included in the sample are incorporated in the United States. Our choice of sample is considered appropriate for the present study since we have a financial interest in the investigation of the likely relationship between female directors and firm's financial performance in the context of the United States technology sector. Data on the United States technology firms listed in the S\&P 500 firms for the year 2016 is obtained from the "YCharts" website at www.ycharts.com, which is a subscription based online service that provides both recent and historical stock market data of publicly traded firms in the United States, as well as, in several other countries worldwide. 
Data on the financial performance for all 49 firms included in the sample is obtained from the "United States Securities and Exchange Commission (SEC)" website at www.sec.gov. The SEC is a publicly accessible online service that uses a database called the "EDGAR" database to track financial statement reports filed by publicly traded firms in the United States. Data on the board of directors for all 49 firms is obtained from the "2020 Women on Boards" website at www.2020wob.com. The 2020 Women on Boards' website is a publicly accessible online service that contains data on the board of directors for over 1800 firms located in the United States, as well as, in several other countries worldwide. The accuracy of the data contained in the 2020 Women on Boards' website cannot be assured

\section{Data Gathering Procedure and Variables}

The YCharts' website offers access to its online service through a 30-day trial plan. It also offers access to its service through an annual subscription fee. Data that is contained in the YCharts' website can be verified using several financial stock market websites like Yahoo Finance and Google Finance. Like the annual subscription plan, the YCharts' 30-day trial plan likewise, offers a download functionality directly from its website, which we used for downloading the data on the United States technology firms listed in the S\&P 500 firms. The data is available for download directly from the website in a comma separated values (CSV) file format. The data obtained from the YCharts' website consists of the following three variables: "ticker, name, and currency code". The "ticker" variable is the stock market symbol for the firm, the "name" variable is the full name of the firm, and the "currency code" variable is the currency used by the firm to trade stock(s) on the American stock exchange markets (i.e. Nasdaq and New York Stock Exchange). 
The financial data on the firms included in our sample is obtained from the SEC website using the ticker symbol of the firm. Using the firm's ticker symbol, we obtained the 10-K financial statement reports for all 49 firms included in our sample for the years 2014 and 2015, which was readily available for download in an excel file format. Five financial variables from the SEC website are included in our sample. They are "netIncome2015, asset2014, asset2015, stock2014, and stock2015". The "netIncome2015" variable is the net income (in United States dollar) earned by the firm for the year 2015. The "asset2014 and asset2015" variables are the monetary value of the total assets (in United States dollar) owned by the firm for the years 2014 and 2015 respectively. Also, the "stock2014 and stock2015" variables are the 2014 and 2015 total stockholder's equity (in United States dollar) attributed to the firm respectively. We used all five of these variables to compute our two financial measures of performance that are required for the present study.

First, we used the netIncome2015, asset2014, and asset2015 variables to compute the return on average assets (ROAA) for all 49 firms included in our sample. The computed ROAA represents the profitability of a firm's assets for the year 2015. A firm's ROAA for the year 2015 is calculated as the percentage ratio of net income (i.e. netIncome2015) and average total assets (i.e. asset2014 and asset2015). Next, we used the netIncome2014, stock2014, and stock2015 variables to compute the return on average equity (ROAE) for all 49 firms included in our sample. The computed ROAE represents the profitability of a firm in relation to the average shareholders' equity for the year 2015. A firm's ROAE for the year 2015 is calculated as the percentage ratio of net income (i.e. netIncome2015) and average stockholder's equity (i.e. stock2014 and stock2015). 
We used several data mining techniques that are provided as packages in the $\mathrm{R}$ statistics software, to obtain data on the board composition of firms from the 2020 Women on Boards' website. The three variables of interest that we obtained from the website are "Board, WOB, and percentWOB". The "Board" variable is the total board size comprising of both male and female directors on the board. The "WOB" variable is the number of women on the board of directors in the firm. The "percentWOB" variable is the percentage ratio of the number of women on the board of directors (indicated by the "WOB" variable) and the total board size in the firm (indicated by the "percentWOB" variable). Table 1 shows a descriptive statistic of some of the aforementioned variables included in our sample.

Table 1

Descriptive Statistics of the Sample Variables

\begin{tabular}{lrrr}
\hline Variable & Min & Max & Mean \\
\hline netIncome2015 & -4359082000.00 & 53394000000.00 & 2985093612.24 \\
asset2014 & 1655578000.00 & 231839000000.00 & 27910588816.33 \\
asset2015 & 1884079000.00 & 290479000000.00 & 30879847959.18 \\
stock2014 & -883466000.00 & 111547000000.00 & 16158950346.94 \\
stock2015 & -1070447000.00 & 120331000000.00 & 16338652551.02 \\
ROAA (percent) & -8.15 & 29.44 & 8.78 \\
ROAE (percent) & -38.41 & 46.41 & 14.78 \\
Board & 5.00 & 15.00 & 10.06 \\
WOB & 0.00 & 5.00 & 1.92 \\
percentWOB & 0.00 & 44.00 & 18.94 \\
\hline
\end{tabular}




\section{CHAPTER IV: STATISTICAL ANALYSIS AND RESULTS \\ Statistical Tool and Selected Significance Level}

We employed the R statistics software to perform the necessary statistical procedures that are required in order to examine the relationship between female directors and financial performance of firms that are included in our sample. The R statistics software combines a comprehensive set of packages for performing nonparametric statistical analysis of the data included in our sample. All statistical analysis, figures, and table reports are generated using the $\mathrm{R}$ statistics software. A 0.05 value was set as the standard significance level for the present study. We used our selected standard significance level as the benchmark to interpret the report of our statistical analysis. We interpreted a $p$ value greater than 0.05 as not significant. Also, we interpreted a $p$ value less than 0.05 as significant.

\section{Shapiro Wilks Test Analysis and Results}

We employed the Shapiro Wilks normality test to analyze the normal distribution of three selected variables included in our sample. We were able to determine the appropriate statistical techniques required for the present study by testing the normality of the following variables: ROAA, ROAE, and percentWOB. The results of the Shapiro Wilks normality test are presented in Table 2 below. We find that the $p$ value for ROAA is less than $0.05(p=0.0044)$. Also, we find that the $p$ value for ROAE is less than $0.05(p=0.0001)$. Furthermore, we find that the $p$ value for percentWOB is less than $0.05(p=0.0231)$.

The results of the Shapiro Wilks normality test for all three variables included in our sample are statistically significant. Thus, the results of the Shapiro Wilks normality test indicate that the sample does not have a normal distribution. For this reason, we employed two nonparametric statistical techniques for analyzing the data included in our sample. The 
"Spearman correlation" analysis (a nonparametric statistical technique) was employed to examine the likely degree of relationship (i.e. correlation) between female directors and financial performance of the firm. We also employed a second nonparametric statistical technique called the "Kruskal Wallis rank sum test" to statistically test the two null hypotheses stated for the present study.

Table 2

Shapiro Normality Test Results

\begin{tabular}{llc}
\hline Variable & Procedure & $p$ value \\
\hline ROAA & Shapiro Wilk normality test & 0.0044 \\
ROAE & Shapiro Wilk normality test & 0.0001 \\
percentWOB & Shapiro Wilk normality test & 0.0231 \\
\hline
\end{tabular}

\section{Spearman Correlation Analysis and Results}

A spearman correlation analysis was used to measure the strength and direction of the monotonic association between two pairs of variables: (1) percentWOB and ROAA and (2) percentWOB and ROAE. Cohen's standard was used to evaluate the strength of the relationships, where coefficients between 0.10 and 0.29 represent a small relationship, coefficients between 0.30 and 0.49 represent a moderate relationship, and coefficients above 0.50 indicate a large relationship (P. Cohen, J. Cohen, West, \& Aiken, 2013). The sign of the coefficient indicates the direction of the relationship. If both variables tend to increase or 
decrease together, the coefficient is positive. If one variable tends to increase as the other decreases, the coefficient is negative.

The spearman correlation analysis assumes that the variables are measured on an ordinal, interval or ratio scale. Our variables included in the sample satisfies this assumption. The spearman correlation analysis also assumes that the relationship between each pair of variables is monotonic (i.e. does not change direction). Also, our variables included in the sample satisfies this assumption. In other words, as one variable increases so do the value of the other variable or as the value of one variable increases, the other variable value decreases. This assumption is violated if the points on the scatterplot diagram between any pair of variables appear to shift from a positive to a negative or a negative to a positive relationship.

We set the significance value at 0.05 . A $p$ value greater than 0.05 allows us to accept the calculated spearman coefficient ( $r h o$ ) as not statistically significant. A $p$ value less than 0.05 allows us to accept the calculated spearman coefficient (rho) as statistically significant. Table 3 shows the calculated $p$ values of the spearman correlation analysis. Table 4 shows the calculated spearman coefficient ( $r h o$ ) of the spearman correlation analysis.

The results of the calculated spearman coefficient (rho) and $p$ values, shows that there was a statistically non-significant negative correlation between percentWOB and ROAA ( $r h o=$ 0.194, $p=0.1819$ ). The spearman coefficient ( $r h o$ ) between percentWOB and ROAA was 0.194, indicating a small negative relationship. The result of the spearman coefficient suggests that as percentWOB increases, ROAA tends to decrease. Furthermore, the results of the calculated spearman coefficient ( $r h o$ ) and $p$ values, shows that there was a statistically significant negative correlation between percentWOB and $\operatorname{ROAE}(r h o=-0.299, p=0.0369)$. The correlation coefficient rho between percentWOB and ROAE was 0.299, indicating a small negative 
relationship. The result of the correlation coefficient suggests that as percentWOB increases,

ROAE tends to decrease.

There was a statistically significant positive correlation between ROAA and ROAE (rho $=0.684, p<0.05)$. The correlation coefficient $(r h o)$ between ROAA and ROAE was 0.684, indicating a large positive relationship. The result of the correlation coefficient suggests that as ROAA increases, ROAE tends to increase.

Table 3

Calculated p Values Among Variables

\begin{tabular}{rrrr}
\hline & ROAA & ROAE & percentWOB \\
\hline ROAA & & 0.0000 & 0.1819 \\
ROAE & 0.0000 & & 0.0369 \\
percentWOB & 0.1819 & 0.0369 & \\
\hline
\end{tabular}

Table 4

Calculated Spearman (rho) Correlation Among Variables

\begin{tabular}{rrrr}
\hline & ROAA & ROAE & percentWOB \\
\hline ROAA & 1.000 & & \\
ROAE & $0.684 * * *$ & 1.000 & \\
percentWOB & -0.194 & $-0.299^{*}$ & 1.000 \\
\hline Significant at $p<.10 ; * p<.05 ; * * p<.01 ; * * * p<.001$
\end{tabular}


Figure 1 shows a scatterplot diagram of the negative correlation between ROAA and percentWOB. Likewise, Figure 2 shows a scatterplot diagram of the negative correlation between ROAE and percentWOB. A scatterplot matrix diagram showing the correlation among the variables (i.e. ROAA, ROAE, and percentWOB) is also shown in Figure 3. The results of the scatterplot diagrams confirm the results of the spearman correlation analysis.

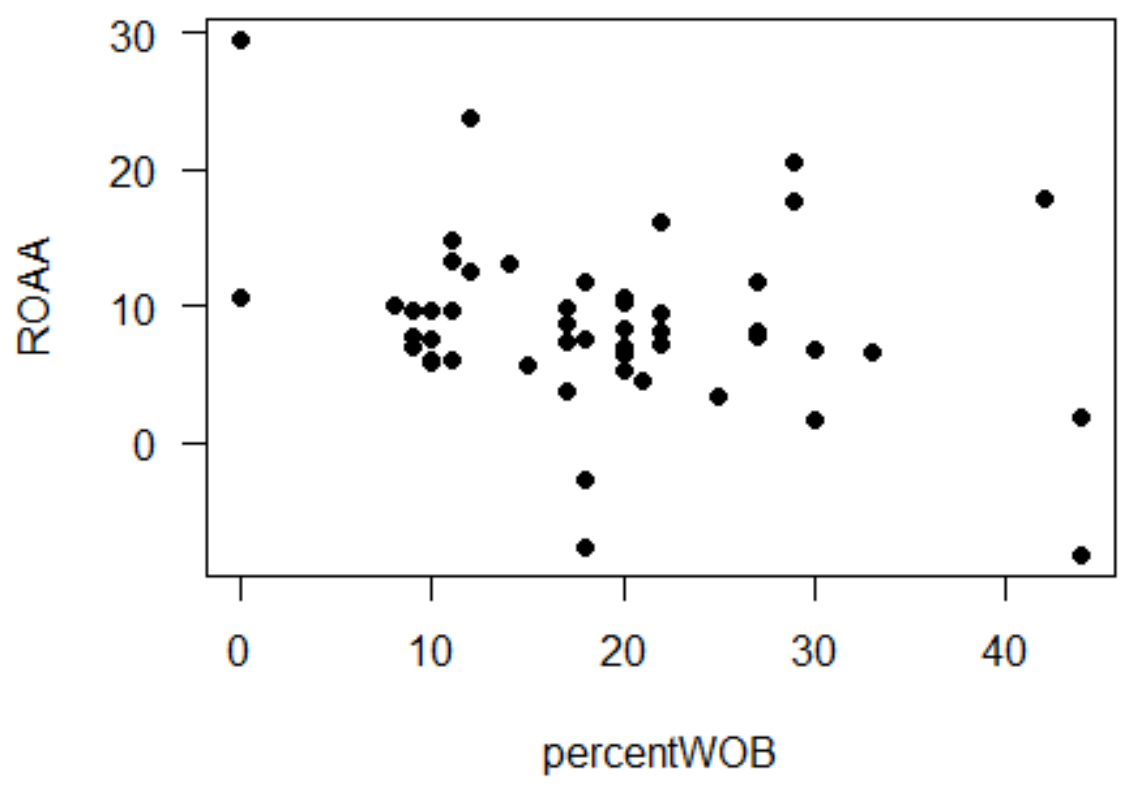

Figure 1. Scatterplot diagram showing the monotonic relationship between ROAA and percentWOB variables. 


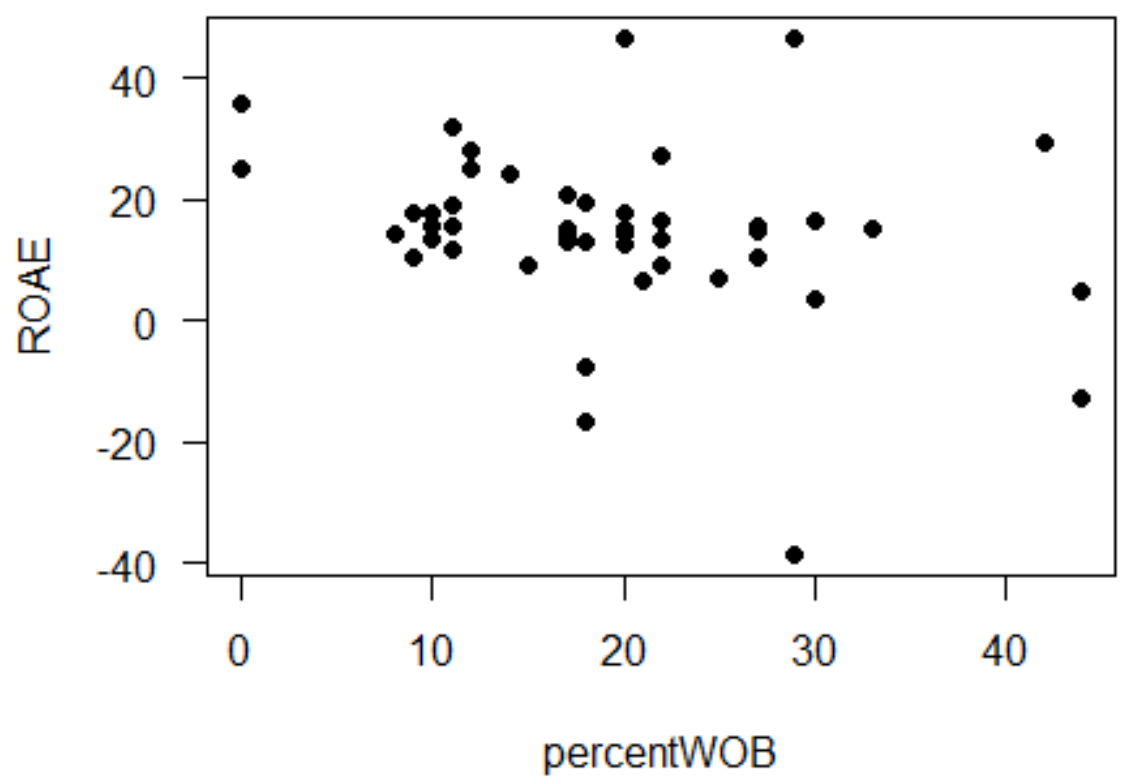

Figure 2. Scatterplot diagram showing the monotonic relationship between ROAE and percentWOB variables. 


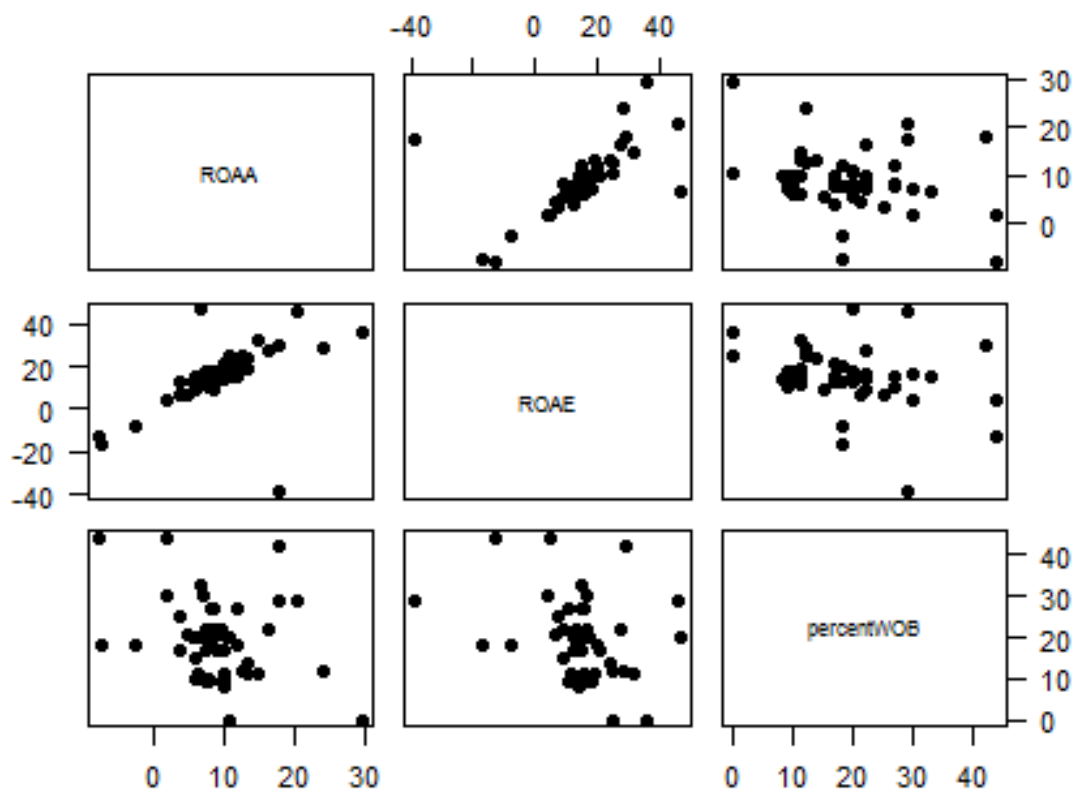

Figure 3. Scatterplot matrix diagram showing the correlation among ROAA, ROAE, and percentWOB variables.

\section{Kruskal Wallis Rank Sum Test Analysis and Results}

We divided our sample into two new data sets in order to test the null hypotheses for the present study. The first data set contains 30 randomly selected firms, including the ROAA financial performance measure for each firm included in the data set. The second data set contains 30 randomly selected firms, including the ROAE financial performance measure for each firm included in the data set.

In each of the data sets, we created two levels or groups using the average (i.e. mean) of percentWOB (see Table 1) from the sample. Each group contained 15 randomly selected firms per data set. The characteristics of the groups are as follows: (1) group 0 consists of 15 randomly 
selected firms from the sample, where the average percentage of women on the board of directors (i.e. average of percentWOB variable) is less than the average percentWOB for all 49 firms included in the sample. (2) group 0 consists of 15 randomly selected firms from the sample, where the average percentage of women on the board of directors (i.e. average of percentWOB variable) is greater than the average percentWOB for all 49 firms included in the sample. Table 5 and Table 6 shows the two data sets that were used for testing our null hypotheses. The two groups included in our newly created data sets, are represented in both tables as the "percentWOBGroup" variable.

A Kruskal Wallis rank sum test was conducted to test the two null hypotheses that are stated for the present study. The Kruskal Wallis rank sum test statistics $(\mathrm{H})$ is given by a rather formidable formula that basically represents the variance of the ranks among groups, with an adjustment for the number of ties. The test statistics $(\mathrm{H})$ is approximately chi-square distributed, meaning that the probability of getting a particular value of $\mathrm{H}$ by chance if the null hypothesis is true, is the $p$ value corresponding to a chi-square equal to $\mathrm{H}$; the degrees of freedom $(d f)$ is the number of groups minus 1 . We set the significance level at 0.05 . If the $p$ value is greater than 0.05 we accept the null hypothesis. If the $p$ value is less than 0.05 we reject the null hypothesis.

The first stated null hypothesis is that the difference in mean of ROAA between the different percentage levels of women on the board of directors (indicated in the first data set as percentWOBGroup variable) is identical. Table 7 shows the results of the Kruskal Wallis test for the first null hypothesis. At a significance level of 0.05 the Kruskal Wallis test showed the $p$ value to be greater than $0.05(p=0.6041)$, indicating a non-significant difference in ROAA between the two percentWOBGroup groups (i.e. group 0 and 1). Also, the test statistics is less than the chi-square tabulation $(0.2688<3.8415)$ with a 1 degree of freedom $(d f)$. Hence we 
accept the null hypothesis and conclude that the difference in mean of ROAA between the different percentage levels of women on the board of directors is identical.

The second stated null hypothesis is that the difference in mean of ROAA between the different percentage levels of women on the board of directors (indicated in the second data set as percentWOBGroup variable) is identical. Table 8 shows the results of the Kruskal Wallis test for the second null hypothesis. At a significance level of 0.05 the Kruskal Wallis test showed the $p$ value to be greater than $0.05(p=0.0930)$, indicating a non-significant difference in ROAE between the two percentWOBGroup groups (i.e. group 0 and 1). Also, the test statistics is less than the chi-square-tabulation $(2.8219<3.8415)$ with a 1 degree of freedom $(d f)$. Hence we accept the null hypothesis and conclude that the difference in mean of ROAE between the different percentage levels of women on the board of directors is identical.

We employed two bar plot diagrams (shown in Figure 4 and Figure 5 below) to verify the result of the Kruskal Wallis test. In both diagrams, we find that the difference in the average financial performance of either the ROAA or ROAE between the two percentWOBGroup groups was almost identical. This shows that there is no significant difference in the overall financial performance of the firms between the varying percentage levels of women on board included in our sample. Fortunately, the results of our bar plot diagrams appear to confirm the result of the Kruskal Wallis test. 
Table 5

First Data Set Showing Average ROAA Between the percentWOBGroup Groups

\begin{tabular}{|c|c|c|c|}
\hline & ROAA & percentWOB & percentWOBGroup \\
\hline 1 & 7.79 & 9 & 0 \\
\hline 2 & -7.56 & 18 & 0 \\
\hline 3 & 13.23 & 11 & 0 \\
\hline 4 & 7.36 & 17 & 0 \\
\hline 5 & 29.44 & 0 & 0 \\
\hline 6 & 7.55 & 18 & 0 \\
\hline 7 & 8.73 & 17 & 0 \\
\hline 8 & 9.72 & 11 & 0 \\
\hline 9 & 7.07 & 9 & 0 \\
\hline 10 & 6.02 & 10 & 0 \\
\hline 11 & 10.57 & 0 & 0 \\
\hline 12 & 5.97 & 11 & 0 \\
\hline 13 & 12.45 & 12 & 0 \\
\hline 14 & 3.70 & 17 & 0 \\
\hline 15 & 9.88 & 17 & 0 \\
\hline 16 & 11.82 & 27 & 1 \\
\hline 17 & 16.23 & 22 & 1 \\
\hline 18 & -8.15 & 44 & 1 \\
\hline 19 & 8.22 & 27 & 1 \\
\hline 20 & 6.56 & 33 & 1 \\
\hline 21 & 7.03 & 20 & 1 \\
\hline 22 & 6.49 & 20 & 1 \\
\hline 23 & 7.18 & 22 & 1 \\
\hline 24 & 1.72 & 30 & 1 \\
\hline 25 & 17.62 & 29 & 1 \\
\hline 26 & 7.85 & 27 & 1 \\
\hline 27 & 6.86 & 30 & 1 \\
\hline 28 & 8.21 & 22 & 1 \\
\hline 29 & 10.61 & 20 & 1 \\
\hline 30 & 5.23 & 20 & 1 \\
\hline
\end{tabular}


Table 6

Second Data Set Showing Average ROAE Between the percentWOBGroup Groups

\begin{tabular}{rrrr}
\hline & ROAE & percentWOB & percentWOBGroup \\
\hline 1 & 28.05 & 12 & 0 \\
2 & 17.60 & 9 & 0 \\
3 & 35.81 & 0 & 0 \\
4 & 11.66 & 11 & 0 \\
5 & 15.11 & 17 & 0 \\
6 & 24.85 & 0 & 0 \\
7 & 15.55 & 10 & 0 \\
8 & 13.35 & 10 & 0 \\
9 & 17.90 & 9 & 0 \\
10 & 19.08 & 11 & 0 \\
11 & 19.53 & 18 & 0 \\
12 & 10.37 & 9 & 0 \\
13 & 12.94 & 18 & 0 \\
14 & 20.80 & 17 & 0 \\
15 & 32.06 & 11 & 0 \\
16 & 6.63 & 21 & 1 \\
17 & 14.97 & 33 & 1 \\
18 & 14.36 & 20 & 1 \\
19 & 10.60 & 27 & 1 \\
20 & 15.44 & 27 & 1 \\
21 & 3.65 & 30 & 1 \\
22 & 4.80 & 44 & 1 \\
23 & 14.58 & 27 & 1 \\
24 & 46.41 & 20 & 1 \\
25 & 27.18 & 22 & 1 \\
26 & 14.93 & 20 & 1 \\
27 & 7.00 & 25 & 1 \\
28 & 16.45 & 30 & 1 \\
29 & 29.37 & 42 & \\
30 & 14.83 & 20 &
\end{tabular}


Table 7

Kruskal Wallis Test of First Null Hypothesis Using the First Data Set

\begin{tabular}{rrrr}
\hline $\mathrm{H}$ & df & $p$ value & chi-square-tabulation \\
\hline 0.2688 & 1 & 0.6041 & 3.8415 \\
\hline
\end{tabular}

Table 8

Kruskal Wallis Test of Second Null Hypothesis Using the Second Data Set

\begin{tabular}{rrrr}
\hline $\mathrm{H}$ & df & $p$ value & chi-square-tabulation \\
\hline 2.8219 & 1 & 0.0930 & 3.8415 \\
\hline
\end{tabular}

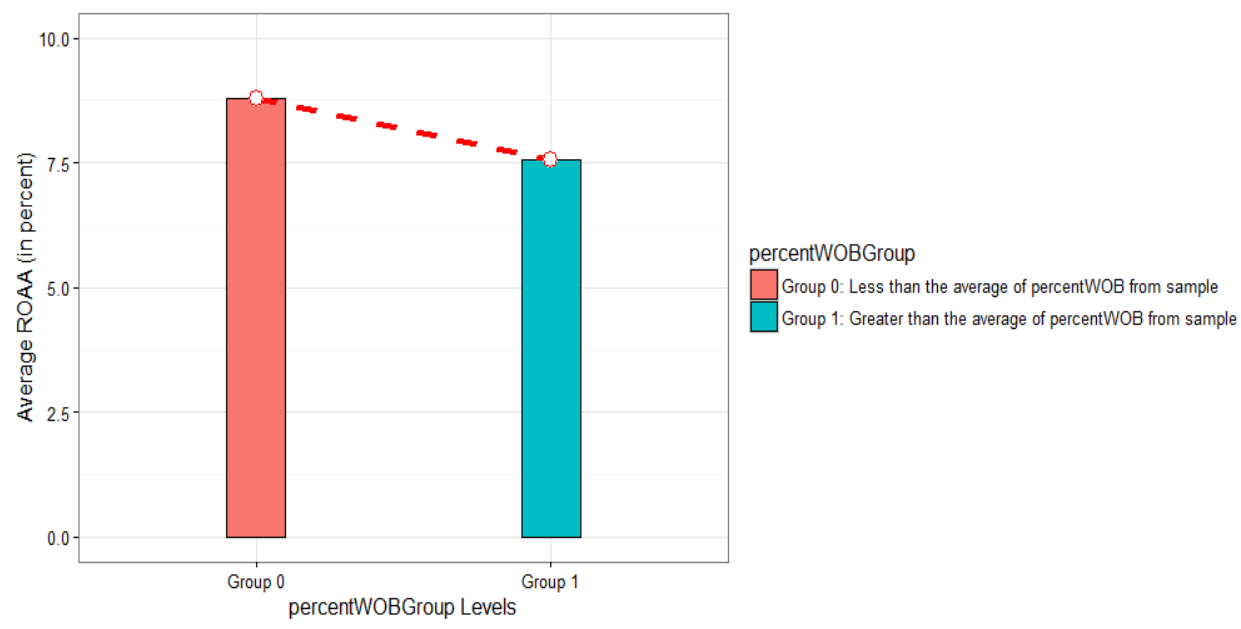

Figure 4. Average ROAA between two percentWOBGroup groups. 


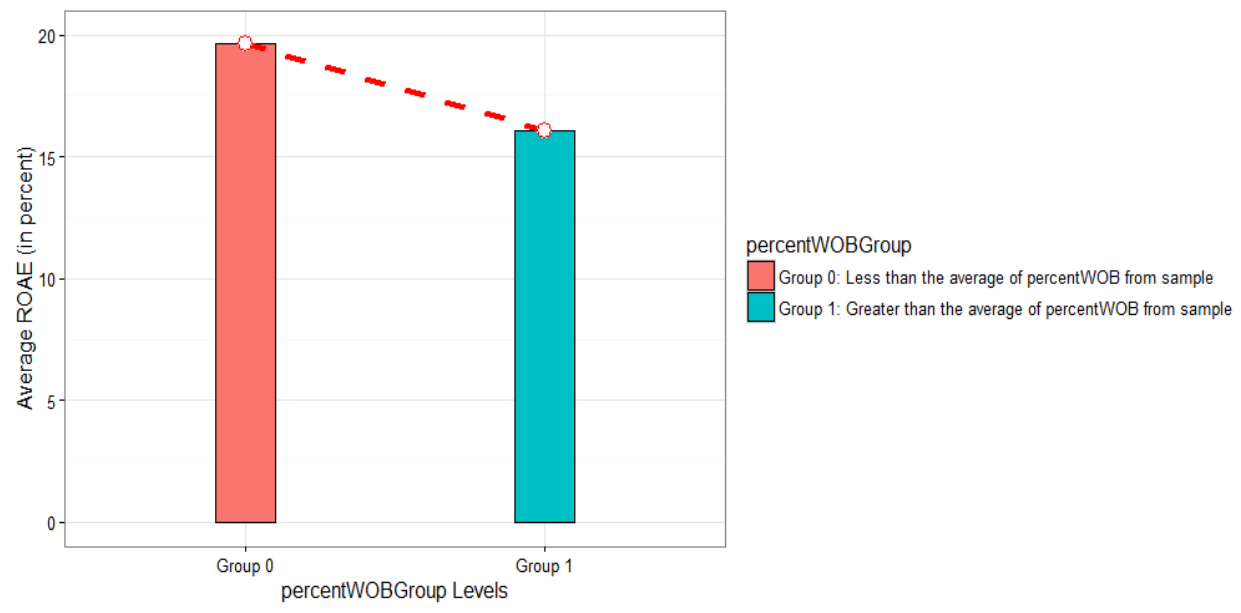

Figure 5. Average ROAE between two percentWOBGroup groups. 


\section{CHAPTER V: CONCLUSION}

This study contributes to the ongoing debate and literature on board diversity and financial performance of the firm. The present study offers new insights into the relationship between the gender diversity of the board and financial performance of the firm. The study follows a descriptive research approach to examine the likely relationship between female directors and financial performance of the firm measured by return on average assets (ROAA) and return on average equity (ROAE). Our sample consists of 49 firms in the United States technology sector, which are listed in the S\&P 500 firms for the year 2016.

The results of our statistical analysis shows a small negative relationship between female directors and financial performance of the firm. Specifically, we find a small but statistically non-significant negative relationship between the percentage of women on the board and financial performance of the firm, measured by ROAA. In a similar approach, we also find a small but significant negative relationship between the percentage of women on the board and financial performance of the firm, measured by ROAE. Also, our sample shows evidence of a low representation of women on the board of directors in firms within the United States technology sector.

We tested two null-hypotheses stated in the present study (see Null Hypotheses). For our first null-hypothesis, we find the average ROAA between the two percentWOBGroup groups, which was created using the average percentage of women on board (i.e. mean of percentWOB) from the sample to be identical. This suggests that there was little or no difference in the ROAA performance of firms included in our sample. Likewise, in our second null-hypothesis test, we find that the average of the ROAE between the two different percentWOBGroup groups is 
identical. This also suggests that there was little or no difference in the ROAE performance of firms included in our sample.

It is important to note the limitations in our research design before drawing any inference from the observed relationship between female directors and firm's financial performance as examined in the present study. First, our research design follows a descriptive approach, which is not considered a strong approach for drawing any inference on the causal (i.e. cause and effect) relationship between female directors and firm's financial performance. Second, the nonparametric statistical techniques employed in the present study is not as strong as the parametric techniques, which are typically used for describing the relationship between female directors and financial performance of the firm. However, our choice of a nonparametric statistical approach was based on the nature of the data included in our sample. This brings us to our third limitation, the size of our sample (i.e. sample size). Our sample consisted of only 49 firms in the United States technology sector, which are listed in the S\&P 500 firms for the year 2016. We assume that our sample size is not large enough to accurately draw any inference on the thousands of technology firms that are incorporated in the United States. Finally, our sample only looks at the financial performance of firms in a two-year period between 2014 and 2015. Due to the small timeline range, we cannot accurately weigh the average performance of firms for over a longer period of time, which could have easily provided us with a more accurate understanding of how the firms included in our sample had performed over the years.

Future research should determine how to resolve the aforementioned limitations of the present study when investigating the likely relationship between female directors and financial performance of the firm. Future research should also consider looking at other factors that may impact the financial performance of the firm. This may include an analysis of the employee size, 
customer size, industry within the technology sector that the firm belongs to, year when the firm was established, and number of successful or failed projects that were executed by the firm. Also, future research should analyze the characteristics of the women who are appointed to the board of directors in technology firms. Some of the female directors' characteristics that future research should pay attention to include the age, income, education background, and race of the female directors, as well as, the committee assignments that they are assigned to, competence level of the managers who they supervise, experience acquired from working on the board of directors in the firm over a given period of time, experience acquired from working on the board of directors in other firms within or outside the technology sector, and family ties to the existing members of the board (if any).

Questions regarding the jurisdiction of the firm (i.e., country of establishment, incorporation, or trading market where the firm operates in), should also be taken into consideration in future research when examining the relationship between female directors and financial performance of the firm. We stress that it is important for future research not to take any biased approach when examining the financial impact of female directors in the context of the United States technology sector. We believe that by expanding the variables in future research, we will be closer into understanding the nature of the relationship between female directors and financial performance of firms in the United States technology sector.

Overall, our results provide evidence of a small negative relationship between female directors and financial performance of the firm. This is consistent with extant studies in the corporate governance literature where also a negative relationship between female directors and financial performance of the firm was reported. However, it is important to note that the difference in the financial performance measures (i.e. ROAA and ROAE) as observed in the test 
of our null-hypotheses, is almost identical for all the firms included in the sample, regardless of the varying number of female directors in those firms. 


\section{REFERENCES}

Adams, R. B., \& Ferreira, D. (2007). A Theory of Friendly Boards. The Journal of Finance, 62(1), 217-250. doi:10.1111/j.1540-6261.2007.01206. x.

Adams, R. B., \& Ferreira, D. (2007). A Theory of Friendly Boards. The Journal of Finance, 62(1), 217-250. doi:10.1111/j.1540-6261.2007.01206. x.

Adams, R. B., \& Ferreira, D. (2009). Women in the boardroom and their impact on governance and performance. Journal of financial economics,94(2), 291-309.

Agrawal, A., \& Knoeber, C. (2001). Do Some Outside Directors Play a Political Role? *. The Journal of Law and Economics, 44(1), 179-198. doi:10.1086/320271.

Ararat, M., Aksu, M. H., \& Tansel Cetin, A. (2010). The impact of board diversity on boards' monitoring intensity and firm performance: evidence from the Istanbul Stock Exchange. Available at SSRN 1572283.

Becker, G. S. (1964). Human capital theory. Columbia, New York.

Booth, J. R., \& Deli, D. N. (1999). On executives of financial institutions as outside directors. Journal of Corporate Finance, 5(3), 227-250. doi:10.1016/s0929-1199(99)00004-8.

Campbell, K., \& Minguez-Vera, A. (2008). Gender diversity in the boardroom and firm financial performance. Journal of business ethics, 83(3), 435-451.

Carter, D. A., D’souza, F., Simkins, B. J., \& Simpson, W. G. (2010). The Gender and Ethnic Diversity of US Boards and Board Committees and Firm Financial Performance. Corporate Governance: An International Review, 18(5), 396-414. doi:10.1111/j.14678683.2010.00809. x. 
Carter, D. A., Simkins, B. J., \& Simpson, W. G. (2003). Corporate Governance, Board Diversity, and Firm Value. Financial Review the Financial Review, 38(1), 33-53. doi:10.1111/15406288.00034.

Coffey, B. S., \& Wang, J. (1998). Board diversity and managerial control as predictors of corporate social performance. Journal of Business Ethics, 17(14), 1595-1603.

Cohen, J., Cohen, P., West, S. G., \& Aiken, L. S. (2013). Applied multiple regression/correlation analysis for the behavioral sciences. Routledge.

Darmadi, S. (2011). Board diversity and firm performance: The Indonesian evidence. Corporate ownership and control Journal, 8.

Erhardt, N. L., Werbel, J. D., \& Shrader, C. B. (2003). Board of director diversity and firm financial performance. Corporate governance: An international review, 11(2), 102-111. doi:10.1111/1467-8683.00011.

Fama, E. F., \& Jensen, M. C. (1983). Separation of ownership and control. The Journal of Law \& Economics, 26(2), 301-325.

Farrell, K. A., \& Hersch, P. L. (2005). Additions to corporate boards: The effect of gender. Journal of Corporate Finance,11(1-2), 85-106. doi: 10.1016/j.jcorpfin.2003.12.001.

Fiedler, F. E., \& Chemers, M. M. (1967). A theory of leadership effectiveness. Goodstein, J., Gautam, K., \& Boeker, W. (1994). The effects of board size and diversity on strategic change. Strategic management journal, 15(3), 241-250.

Hillman, A. J., Cannella, A. A., \& Harris, I. C. (2002). Women and Racial Minorities in the Boardroom: How Do Directors Differ? Journal of Management, 28(6), 747-763. doi:10.1177/014920630202800603. 
Ibarra, H. (1993). Personal Networks Of Women And Minorities In Management: A Conceptual Framework. Academy of Management Review, 18(1), 56-87. doi:10.5465/amr.1993.3997507.

Jensen, M. C., \& Meckling, W. H. (1976). Theory of the firm: Managerial behavior, agency costs and ownership structure. Journal of Financial Economics, 3(4), 305-360. doi:10.1016/0304-405x(76)90026-x.

Kakabadse, N. K., Figueira, C., Nicolopoulou, K., Hong Yang, J., Kakabadse, A. P., \& Ozbilgin, M. F. (2015). Gender Diversity and Board Performance: Women’s Experiences and Perspectives. Human Resource Management, 54(2), 265-281.

Lau, D. C., \& Murnighan, J. K. (1998). Demographic Diversity and Faultlines: The Compositional Dynamics of Organizational Groups. Academy of Management Review, 23(2), 325-340. doi:10.5465/amr.1998.533229.

Lawrence, P. R., \& Lorsch, J. W. (1967). Organization and environment: Managing differentiation and integration. Harvard Business School Press, Boston, MA.

Minguez-Vera, A., \& Martin, A. (2011). Gender and management on Spanish SMEs: An empirical analysis. The International Journal of Human Resource Management, 22(14), 2852-2873. doi:10.1080/09585192.2011.599948.

Oxelheim, L., \& Randoy, T. (2003). The impact of foreign board membership on firm value. Journal of Banking \& Finance, 27(12), 2369-2392.

Pfeffer, J., \& Salancik, G. R. (2003). The external control of organizations: A resource dependence perspective. Stanford University Press. 
Rose, C. (2007). Does female board representation influence firm performance? The Danish evidence. Corporate Governance: An International Review Corporate Governance, 15(2), 404-413. doi:10.1111/j.1467-8683.2007.00570.x.

Shrader, C. B., Blackburn, V. B., \& Iles, P. (1997). Women in management and firm financial performance: An exploratory study. Journal of managerial issues, 355-372.

Smith, N., Smith, V., \& Verner, M. (2006). Do women in top management affect firm performance? A panel study of 2,500 Danish firms. International Journal of productivity and Performance management, 55(7), 569-593. doi:10.1108/17410400610702160.

Terjesen, S., Sealy, R., \& Singh, V. (2009). Women Directors on Corporate Boards: A Review and Research Agenda. Corporate Governance: An International Review, 17(3), 320-337. doi:10.1111/j.1467-8683.2009.00742.x.

United States Tech Industry Employs 6.5 Million in 2014. (2015, Feb 10). Retrieved October 24, 2016, from https://www.comptia.org/about-us/newsroom/ pressreleases/2015/02/10/united-states-tech-industry-employs-6.5-million-in-2014.

Westphal, J. D., \& Milton, L. P. (2000). How Experience and Network Ties Affect the Influence of Demographic Minorities on Corporate Boards. Administrative Science Quarterly, 45(2), 366. doi:10.2307/2667075. 